\title{
Analysis of Learning Outcomes in Medical Education with the Use of Fuzzy Logic
}

\author{
Jacek Stańdo ${ }^{1}$, Iwona Mokwa-Tarnowska ${ }^{2}$, Magdalena Roszak $^{3}$ \\ 1 Centre of Mathematics and Physics, Lodz University of Technology, Poland \\ 2 Language Centre, Gdańsk University of Technology, Poland \\ 3 Department of Computer Science and Statistics, Poznan University of Medical Sciences, \\ Poland
}

\begin{abstract}
The national curricula of the EU member states are structured around learning outcomes, selected according to Bloom's Taxonomy. The authors of this paper claim that using Bloom's Taxonomy to phrase learning outcomes in medical education in terms of students' achievements is difficult and unclear. This paper presents an efficient method of assessing course learning outcomes using Fuzzy Logic.
\end{abstract}

\section{Introduction}

In 1999, the Ministers of Education of 29 European countries signed the Bologna Declaration. It aimed to:

- introduce a system of transparent and comparable degrees,

- promote student mobility,

- tailor education systems to meet the needs of the labour market.

For the comparability of qualifications, in 2008 the European Union developed the European Qualifications Framework (EQF) and revised it in 2017 (Europass. European Union., 2017). "Each of the 8 levels of the EQF is defined by a set of descriptors indicating the learning outcomes relevant to qualifications at that level in any qualifications system" (Europass. European Union, 2021). The Polish Qualifications Framework (PQF) consists of eight levels, compatible with the EQF. It distinguishes full and partial qualifications. A Master's degree in medicine is a level 7 qualification both in the PQF and the EQF.

The wording of the EQF shows that the approach to education has changed (Niemierko, 2021). The emphasis has shifted from the lecturer's point of view on what should be taught and how it should be done to what 
students will know and will be able to do (Kraśniewski, 2009). The concept of "learning outcomes" has become the most important one to describe the educational process.

\section{Principal Definitions}

Definition 1. Learning outcomes are "statements about what a learner knows, understands and is able to do on completion of a learning process they are defined in terms of knowledge, skills and responsibility and autonomy" (Europass. European Union., 2017).

Definition 2. "Knowledge means the outcome of the assimilation of information through learning. Knowledge is the body of facts, principles, theories and practices that is related to a field of work or study. In the context of the EQF, knowledge is described as theoretical and/or factual" (Europass. European Union., 2017)

Definition 3. "Skills means the ability to apply knowledge and use knowhow to complete tasks and solve problems. In the context of the EQF, skills are described as cognitive (involving the use of logical, intuitive and creative thinking) or practical (involving manual dexterity and the use of methods, materials, tools and instruments (Europass. European Union., 2017).

Definition 4. "Competence means the proven ability to use knowledge, skills and personal, social and/or methodological abilities, in work or study situations and in professional and personal development" (Europass. European Union., 2017).

\section{Classification of Learning Outcomes}

The term "classification", which in logic means the grouping of objects into a set according to their properties, is often used synonymously with the term "taxonomy". Originally, "taxonomy" denoted the classification of living and extinct organisms, animals and plants; then the scope of the term was expanded to cover a more general system of naming and organization. It aims to name, classify, and structure items in levels (Tomaszczyk, 2007). The best known and widely used taxonomy of learning outcomes is the one based on Bloom's Taxonomy of Educational Objectives (Bloom, 1956), later revised by Anderson and Krathwohl (Anderson, et al. 2001), as shown in Figure 1. 


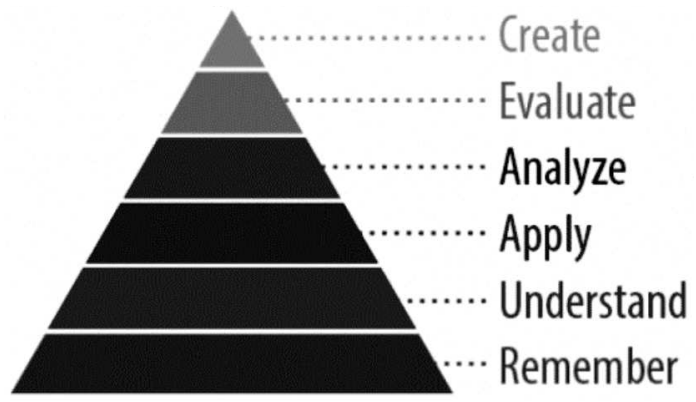

Figure 1. Revised Bloom's Taxonomy (Anderson et al., 2001)

\section{Description of Categories}

1. Knowledge - remembering material.

The category encompasses recalling a definition, claim or formulae, and understanding simple facts.

2. Comprehension means the ability to understand and interpret meaning.

3. Application means the ability to use objects in new situations.

4. Analysis means problem decomposition, recognition of relations between separate objects.

5. Evaluation means object evaluation, discussing ideas and convincing others to accept ideas, and drawing conclusions.

6. Creation means linking achievements, building new principles and objects, including criticism.

Having taxonomic categories established, learning outcomes can be classified and interrelations between them analysed. Unfortunately, there appears the difficulty to adequately assign a category to an already defined learning outcome. To overcome it, the fuzzy set theory can be used (Zadeh, 1965).

In the classical set theory, it is defined whether an element belongs to a set or not. In exact sciences, e.g. mathematics, a mathematical statement is either true or false. It is worth emphasising, though, that in mathematics there are hypotheses that are yet to be verified, e.g. Goldbach's conjecture, even if substantial research shows that it is empirically true.

In the language of analysis, qualifying statements often appear, i.e. that method A is better that method B. There are also classifications of an object i.e. small, tall, medium. If necessary, some classifications can even be more detailed, i.e. very small, small, medium, tall, very tall. Fuzzy logic is used in such analyses. 
Jacek Stańdo, Iwona Mokwa-Tarnowska, Magdalena Roszak

\section{Elements of Fuzzy Logic}

According to Zadech (1965), fuzzy set $A$ is a set of ordered pairs:

$$
A=\left\{\left(X, \mu_{A}(x)\right): x \in X\right\}
$$

where $\mu_{A}: x \rightarrow[0,1]$ function is called the membership function of fuzzy set $A$.

The following three cases are considered:

1) If $\mu_{A}(x)=1$, then element $x$ fully belongs to set $A$.

2) If $\mu_{A}(x)=0$, does not belong to set $A$.

$3)$ If $0<\mu_{A}(x)<1$, then element $x$ partially belongs to set $A$.

\section{Fuzzification and Defuzzification of Learning Outcomes}

Let $x$ be an assumed learning outcome. Let $A_{i}$ denote, for $i=$ $1,2, \ldots, 5,6$, a set close to $i$-th Bloom's category. For example, $A_{3}$ is the set close to the category Apply. Learning outcomes will be modelled using fuzzy logic and Bloom's taxonomy. Figure 2 shows the scheme of a fuzzy model.
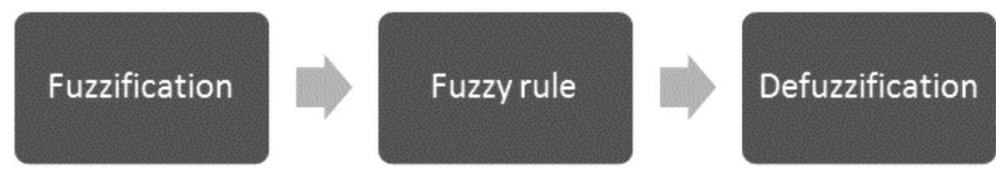

Figure 2. Fuzzy model

The fuzzy definition of a linguistic variable is given in Figure 3. Fuzzification is defined as the process of transforming a crisp set into a fuzzy set. Fuzzification is done using 3 fuzzy linguistic variables: "high", "medium", and "low".

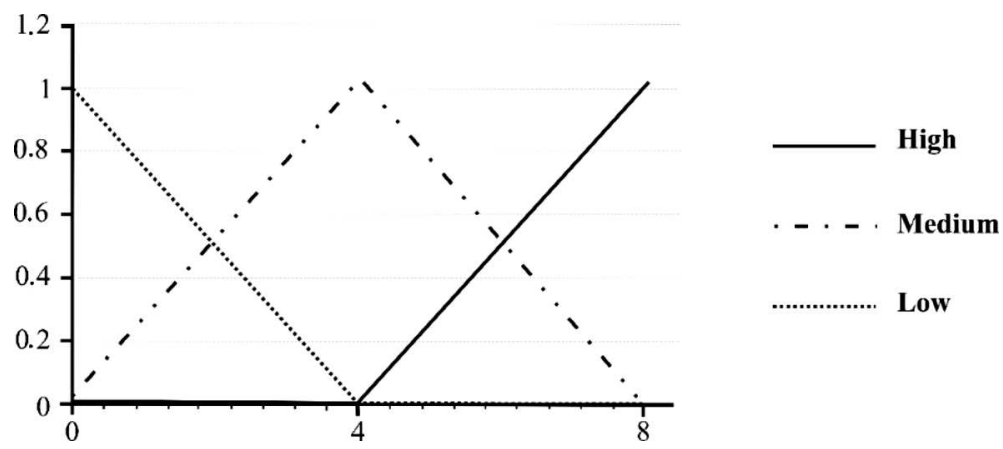

Figure 3. Fuzzification 
Analysis of Learning Outcomes in Medical Education with the Use...

Let the following functions be defined using the following formulas:

$$
\begin{aligned}
& \mu_{L}(x)=\left\{\begin{array}{ll}
\frac{-x+4}{4} & x \in[0,4] \\
0 & x \in(4,8]
\end{array} \quad \mu_{M}(x)= \begin{cases}\frac{x}{4}-x+8 & x \in[0,4] \\
\frac{-x}{4} & x \in(4,8]\end{cases} \right. \\
& \mu_{H}(x)= \begin{cases}0 & x \in[0,4] \\
\frac{x-4}{4} & x \in(4,8]\end{cases}
\end{aligned}
$$

where: $\mu_{L}: x \rightarrow[0,1]$ membership function to set $L-$ low, $\mu_{M}: x \rightarrow[0,1]$ membership function to set $M$ - medium, $\mu_{H}: x \rightarrow[0,1]$ membership function to set $H$ - high.

Defuzzification is defined as the process of reducing a fuzzy set into a crisp set. The method of Maximum (Naaz et al., 2011) is used, which is presented in Figure 4.

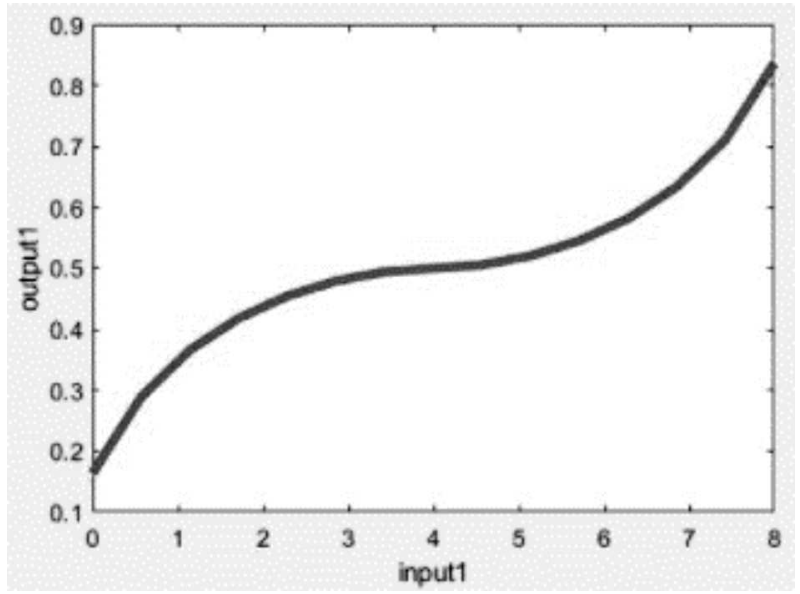

Figure 4. Defuzzification

\section{Analysis of Selected Learning Outcomes}

The procedure to be followed is:

1. Select a learning outcome.

2. Choose a category from Bloom's Taxonomy.

3. Determine the matching by indicating the argument of the function.

4. Find the values of the matching.

Analysis of the selected learning outcome can be summarized in the table proposed below (Table 1). 
Jacek Stańdo, Iwona Mokwa-Tarnowska, Magdalena Roszak

Table 1. Learning Outcome

\begin{tabular}{|c|c|c|c|c|c|c|}
\hline \multirow{2}{*}{\multicolumn{2}{|c|}{ Bloom's taxonomy }} & \multicolumn{4}{|c|}{ Membership function } & \multirow{3}{*}{ Defuzzification } \\
\hline & & \multirow{2}{*}{$\begin{array}{c}\text { Argument } \\
\mathrm{x}\end{array}$} & \multicolumn{3}{|c|}{ Value } & \\
\hline $\begin{array}{c}\text { Category } \\
\text { name }\end{array}$ & $\begin{array}{c}\text { Name of } \\
\text { the set }\end{array}$ & & Low & Medium & High & \\
\hline Remember & $A_{1}$ & & & & & \\
\hline Understand & $A_{2}$ & & & & & \\
\hline Apply & $A_{3}$ & & & & & \\
\hline Analyze & $A_{4}$ & & & & & \\
\hline Evaluate & $A_{5}$ & & & & & \\
\hline Create & $A_{6}$ & & & & & \\
\hline
\end{tabular}

Education of future medical doctors is based on a standard that prepares them for performing the professions of a medical doctor, dental practitioner, pharmacist, nurse, midwife, laboratory diagnostician, physiotherapist, and paramedic. In Annex 1 to the Regulation of the Minister of Science and Higher Education of 2019 on the standards of education preparing for performing the profession of the medical doctor, a group of classes is described in the course of which the student achieves detailed learning outcomes. 5 general learning outcomes in terms of knowledge (graduate knows and understands) are defined; in terms of skills (graduate is able to), 9 effects are defined; in terms of social competences (graduate is ready to), 11 effects are defined.

Detailed learning outcomes include effects defined for: morphological sciences (knowledge - 6 effects, skills - 5 effects), scientific bases of medicine (knowledge - 29 effects, skills - 13 effects), preclinical sciences (knowledge - 51 effects, skills - 20 effects), behavioural and social sciences with elements of professionalism (knowledge - 23 effects, skills - 18 effects), non-surgical clinical sciences (knowledge - 43 effects, skills - 38 effects), surgical clinical sciences (knowledge - 16 effects, skills - 26 effects), legal and organizational aspects of medicine (knowledge - 18 effects, skills - 9 effects).

An analysis of selected learning outcomes according to the presented theoretical approach on the basis of detailed learning outcomes will be presented in the next article. It should be performed on all the outcomes, which would make it possible to obtain a clear picture of the whole curriculum, divided into Bloom's categories (Krathwohl, 2002). Such work should be performed with participation of experts in a given subject matter, in order to properly interpret the obtained conclusions (Leszczyński 
Analysis of Learning Outcomes in Medical Education with the Use...

et al., 2017, Mokwa-Tarnowska, et al., 2018; Stańdo, 2019). In the area of education, many authors have already been using fuzzy logic as a tool (Pasikowski, 2017).

\section{Conclusion}

Before a proposed approach is implemented on a larger scale, it is necessary to test it, including testing in the areas of medical sciences and health sciences.

There are no teachers who would not have doubts as to which Bloom's Taxonomy category should be ascribed to the chosen learning outcome. The used method that employs fuzzy logic defines new directions for solving the problem. It would be beneficial to implement the European Qualifications Framework for education at medical universities. Tests performed by academic teachers from medical universities are necessary. Hence, a scientific debate concerning the achieved effects in terms of the proposed tools is needed, which would include fuzzy logic.

\section{Acknowledgments}

The authors acknowledge the teachers, administrative staff, and technicalengineering staff from Lodz University of Technology in Poland who agreed to participate in these study.

\section{R E F E R E N C E S}

Anderson, L. W. (Ed.), Krathwohl, D. R. (Ed.), Airasian, P. W., Cruikshank, K. A., Mayer, R. E., Pintrich, P. R., Raths, J., \& Wittrock, M. C. (2001). A taxonomy for learning, teaching, and assessing: A revision of Bloom's Taxonomy of Educational Objectives (Complete edition). New York: Longman.

Bloom B. (Ed.) (1956). Taxonomy of Educational Objectives, Handbook I: The Cognitive Domain. New York: David McKay Co Inc.

Europass. European Union. (2017). Description of the eight EQF levels. Retrieved from: https://europa.eu/europass/en/description-eight-eqf-levels

Europass. European Union. (2021). Description of the eight EQF levels. Retrieved from: https://europa.eu/europass/en/description-eight-eqf-levels

Kraśniewski, A. (2009). Proces Boloński: to już 10 lat. Fundacja Rozwoju Systemu Edukacji, Warszawa. Retrieved from: https://docplayer.pl/14272-Andrzejkrasniewski-proces-bolonski-to-juz-10-lat.html

Krathwohl, D. R. (2002). A Revision of Bloom's Taxonomy: An Overview, Theory Into Practice, 41(4), 212-264. 
Leszczyński, P., Charuta, A., Łaziuk, B., Gałązkowski, R., Wejnarski, A., Roszak, M., \& Kołodziejczak, B. (2017). Multimedia and interactivity in distance learning of resuscitation guidelines: a randomised controlled trial. Interactive Learning Environments, 26(37), 1-12. doi: 10.1080/10494820.2017. 1337035

Mokwa-Tarnowska, I., Kołodziejczak, B., \& Roszak, M. (2018). Od zajęć wspomaganych narzędziami internetowymi do kursów online - efektywność nowych środowisk uczenia się w opiniach studentów, Zeszyty Naukowe Wydziału Elektrotechniki i Automatyki Politechniki Gdańskie, 58, 57-62.

Naaz, S., Alam, A., \& Biswas R. (2011). Effect of Different Deffuzification Methods in a Fuzzy Based Load Balancing Application. IJCSI International Journal of Computer Science, 8(5), 1.

Niemierko, B. (2021). Diagnostyka edukacyjna. Warszawa: Wydawnictwo Naukowe PWN.

Pasikowski, S. (2017). The Threats of Heterogeneous and Fuzzy Variables Measurement in Research in Education. Przeglad Badań Edukacyjnych (Educational Studies Review), 1(24), 209-221.

Stańdo, J. (2019). Trajektorie i walidacja efektów uczenia się w kontekście Polskiej Ramy Kwalifikacji. Łodź: Wydawnictwo Politechniki Łódzkiej.

Tomaszczyk, J. (2007). Taksonomia jako narzędzie organizacji informacji. Zagadnienia Informacji Naukowej, nr 1. Retrieved from: http://bbc.uw.edu.pl/ Content/1789/z2007_1_04.pdf

Zadeh, L. A. (1965). Fuzzy sets. Information and Control, 8, 338-353. 